\title{
The Effect of Religion on Fertility Differentials
}

\section{FJALAR FINNÄS}

Research Director, Docent

Åbo Akademi

Social Science Research Unit

\section{Introduction}

In demography we often compare region, and vital statistics are published for provinces as well as for single municipalities. If we know the structure of the population such comparisons can give some ideas of the factors affecting demographic development. However, it is very difficult to actually measure the effect of the different background variables in this way. For studies of that kind individual survey data are needed.

In Finland there have been considerable regional differences in the fertility level. Around 1950 the total fertility rate in the provinces of Lapland and Oulu was a good 4.5, whereas it was only about 2.1 in the province of Uusimaa. The differences have diminished during the post-war period, but they still exist. In 1987 the total fertility rate varied between 1.47 and 1.96 in the provinces. (See Figure 1) The provinces are not homogeneous with respect to fertility, and the differences at the municipality level are much bigger. For the period $1985-87$ the rates ranged from 1.08 to 3.39 . For a more detailed illustration of the regional variations, the average total fertility rates for all municipalities for the period 1980-87 are shown in the map in Figure 2.

Figure 1. Total fertility rate by province $1910-1987$.

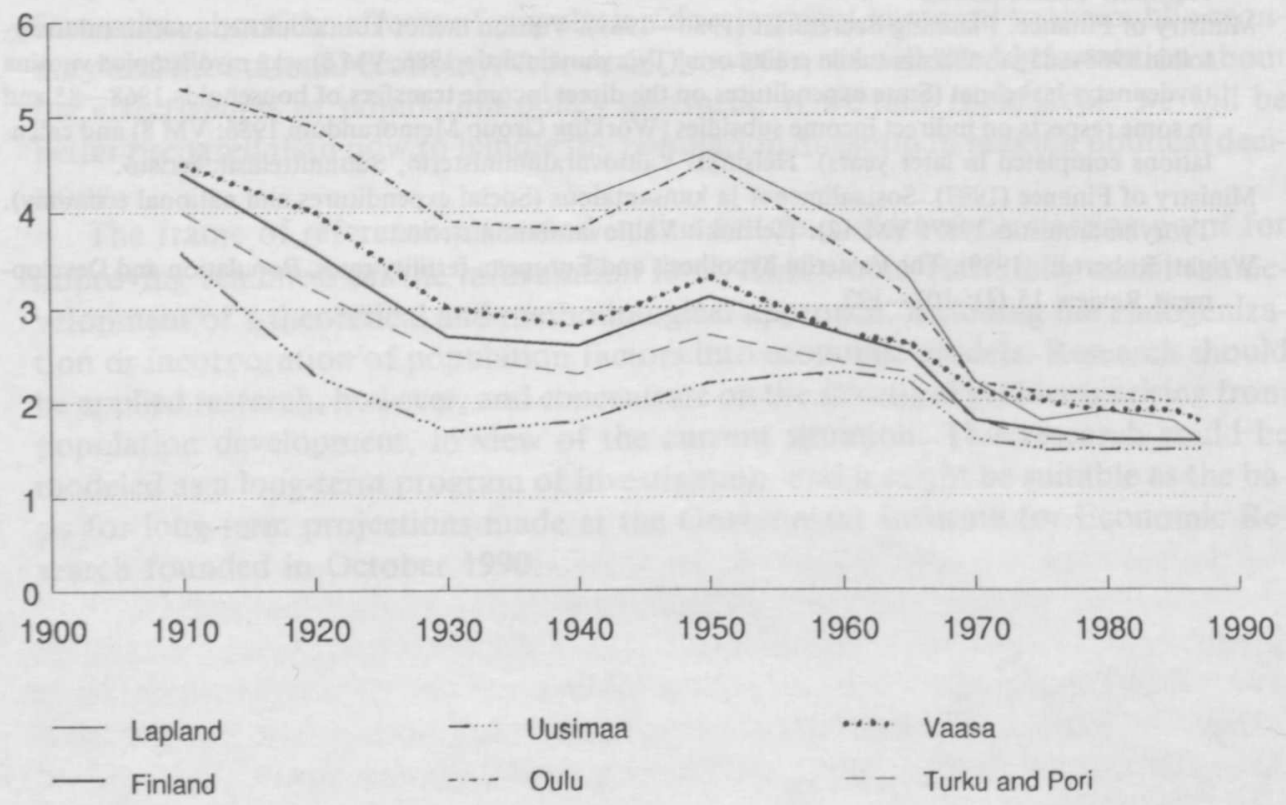


Figure 2. Total fertility rate $1980-87$ by municipality.

Total fertility rate
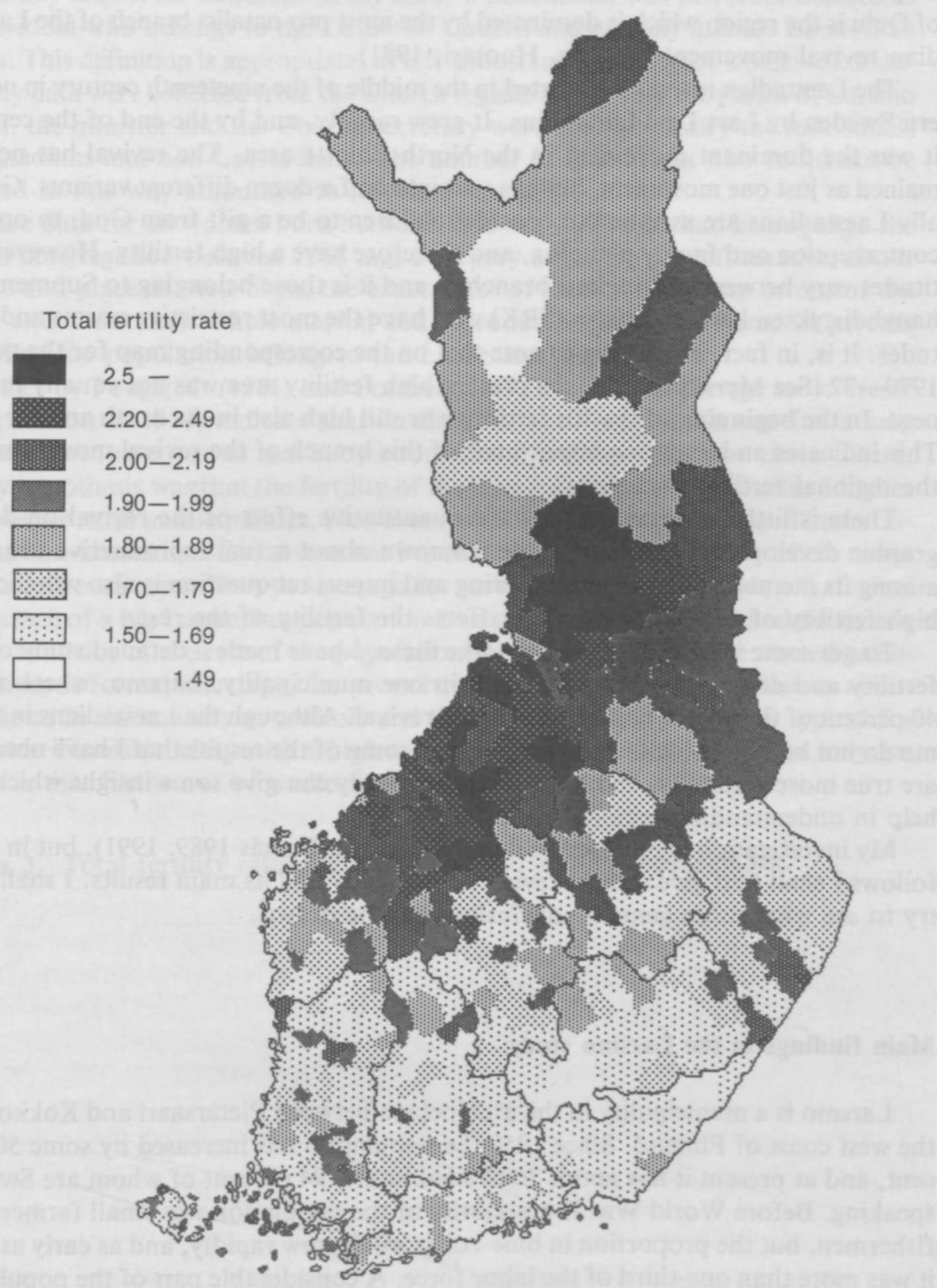

In 71 out of the 461 municipalities, i.e. 15 percent, the total fertility rate exceedes 2.1. which is required for a net reproduction rate of 1.0 . However, since these municipalities are rather small, they represent only about 6 percent of the total population in Finland. On the other hand a good 21 percent of the population live in the 25 municipalities where the total fertility rate is below 1.5. 
The traditional explanations for the regional variations have been differences in industrialization, urbanization, education and the like. The map reflects these variables, but it also shows the great importance of another variable, namely religion. At present the area where fertility is the highest, i.e. the western part of the province of Oulu is the region which is dominated by the most pro-natalist branch of the Laestadian revival movement (See e.g. Huotari, 1981).

The Laestadian revival was started in the middle of the nineteenth century in northern Sweden by Lars Levi Laestadius. It grew rapidly, and by the end of the century it was the dominant movement in the North Calotte area. The revival has not remained as just one movement, but has split into half a dozen different variants. Generally Laestadians are assumed to consider children to be a gift from God, to oppose contraception and family planning, and therefore have a high fertility. However, attitudes vary between the various branches, and it is those belonging to Suomen rauhanyhdistyksen keskusyhdistys (SRK) who have the most restrictive norms and attitudes. It is, in fact, interesting to note that on the corresponding map for the period 1970 - 72 (See Myrskylä 1976) the present high fertility area was not equally prominent. In the beginning of the 70 s fertility was still high also in the north and the east. This indicates an increasing importance of this branch of the revival movement for the regional fertility variations.

There is little knowledge about the quantitative effect of the revival on demographic development, and very little is known about actual reproductive behavior among its members. One very interesting and important question is also whether the high fertility of one subpopulation affects the fertility of the rest.

To get some idea about questions like these, I have made a detailed study of the fertility and demographic development in one municipality, Larsmo, where about 40 percent of the population belongs to the revival. Although the Laestadians in Larsmo do not belong to SRK, I still believe that some of the results that I have obtained are true more generally, and I hope that my study can give some insight which will help in understanding regional variations.

My investigation is reported in detail elsewhere (Finnäs 1989, 1991), but in what follows I shall first give a short review of the study and its main results. I shall then try to see what more general conclusions can be drawn.

\section{Main findings in the Larsmo study}

Larsmo is a municipality in the archipelago between Pietarsaari and Kokkola on the west coast of Finland. Since 1950 the population has increased by some 50 percent, and at present it has about 3600 inhabitants, 94 percent of whom are Swedish speaking. Before World War II a majority of the population was small farmers and fishermen, but the proportion in blue-collar work grew rapidly, and as early as 1960 it was more than one-third of the labor force. A considerable part of the population is employed in the neighboring towns. During the period 1980-87 the total fertility rate was 3.2, which is the second highest for all municipalities in Finland.

The main area of Laestadianism is the North Calotte area, with Finnish as the dominant language also in Sweden and Norway. However, Laestadians can also be found in the Swedish-speaking areas in Ostrobothnia in Finland. The revival came to Larsmo in the 1880s. The Swedish-speaking Laestadians in Ostrobothnia have their own organization Laestadianernas fridsföreningars förbund, and according to Suolinna (1988) they have very much in common with those in the Torneå valley in Sweden. 
This branch of the revival is conservative and very pro-natalistic and, in this respect, is probably comparable with those who belong to SRK.

Laestadians belong to the Lutheran Church, but hold their own church services and Sunday school for children. In my study a Laestadian was therefore defined as an individual who belongs to the Lutheran Church and actively attends Laestadian services. This definition is appropriate, as it is almost impossible to be a passive Laestadian. My data were collected from the Church registers, and since the parish of Larsmo is small, the minister and the Church secretary were able to classify the individuals as Laestadians and non-Laestadians. The number of individuals who could not be classified in this way amounted to less than one percent.

I have data for all women born between 1930 and 1970 who had belonged to the Larsmo congregation between 1968 and February 1988. I have information about the date and place of their birth, the exact dates of their moving into or out of the parish, and about their whole marital and reproductive histories. Some 94 percent of the Larsmo population belong to the Lutheran Church.

Studies by Fougstedt (1951) and Forsberg (1977), as well as the age structure of the population in 1950, indicate that fertility has been high in Larsmo for a long time, and that there was no real baby-boom during the first post-war years. Therefore my hypothesis was that the fertility of the non-Laestadians has remained higher than in other rural municipalities. However, this turned out to be wrong. The fertility of the non-Laestadians in Larsmo has been at the average level for the whole country, which is even lower than the average for rural municipalities (Figure 3). In fact the presence of a big Laestadian population does not seem to have affected the demographic behavior of the rest of the population. Non-Laestadians have started to cohabit without formal marriage, the proportion of pre-marital conceptions is about the same as in the country as a whole and the parity distribution is very typical for the present Finnish society with a high concentration of two children. The only exception is that births out of wedlock are still very rare.

Figure 3. Total fertility rate in Finland and Larsmo by congregation.

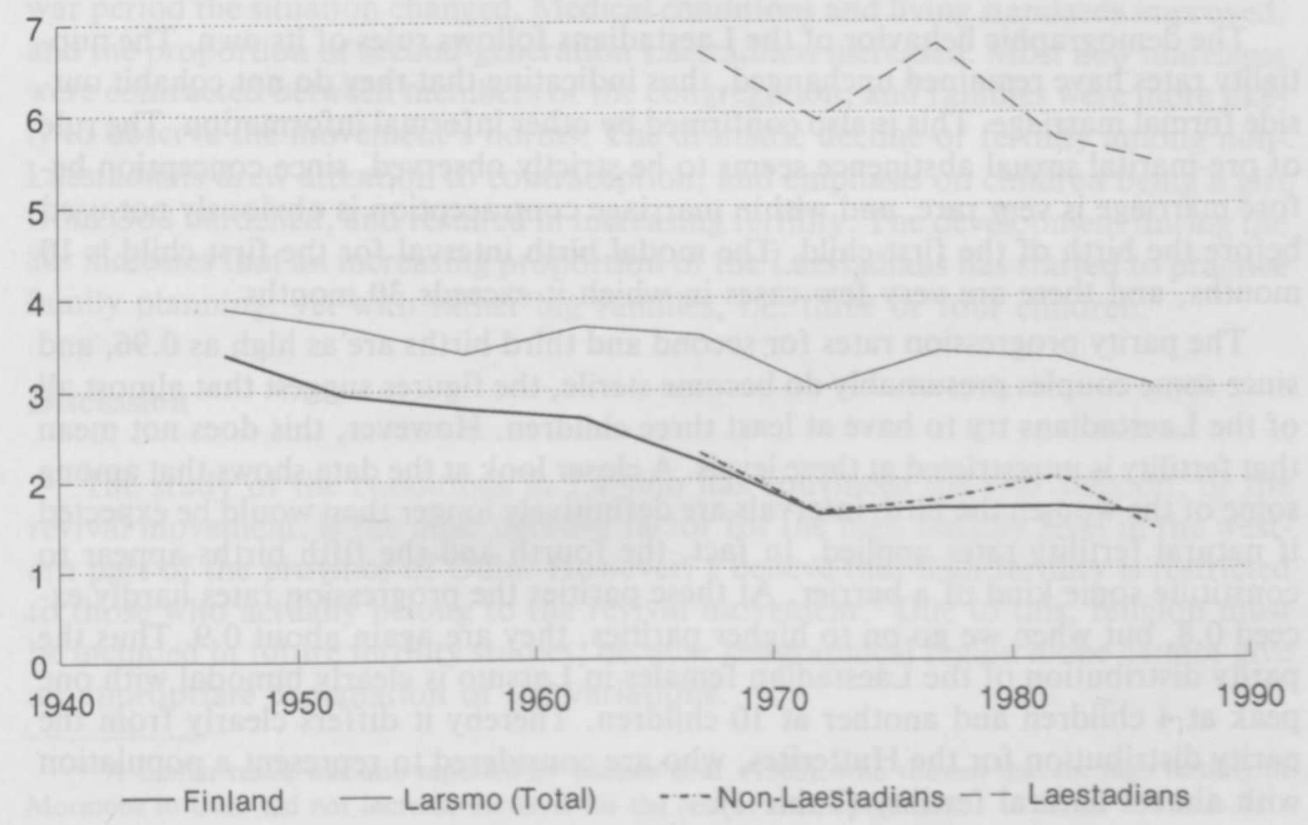


Figure 4. The parity progression rates for selected durations since previous birth.

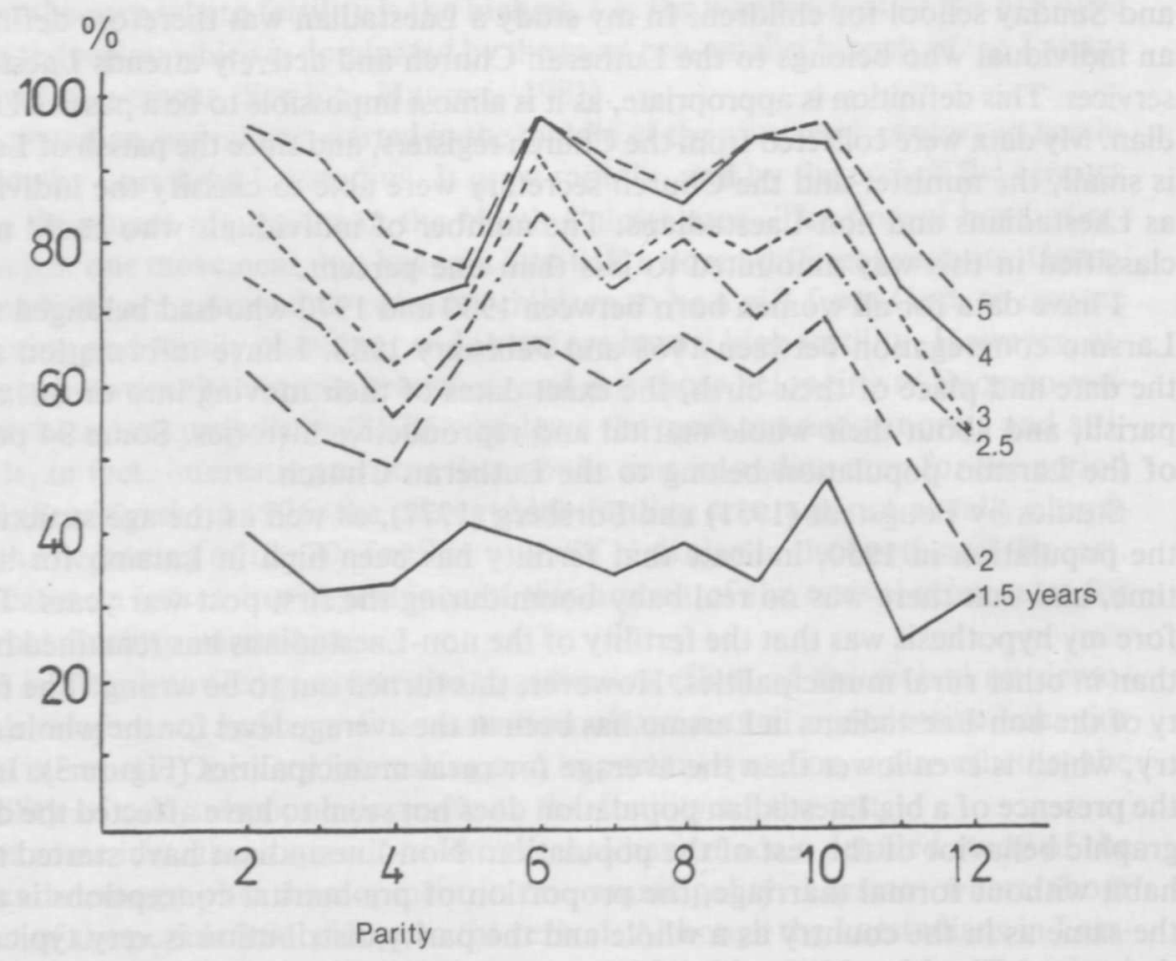

The demographic behavior of the Laestadians follows rules of its own. The nuptiality rates have remained unchanged, thus indicating that they do not cohabit outside formal marriage. This is also confirmed by other informal information. The rule of pre-marital sexual abstinence seems to be strictly observed, since conception before marriage is very rare, and within marriage contraception is obviously not used before the birth of the first child. The modal birth interval for the first child is 10 months, and there are very few cases in which it exceeds 30 months.

The parity progression rates for second and third births are as high as 0.96 , and since some couples presumably do become sterile, the figures suggest that almost all of the Laestadians try to have at least three children. However, this does not mean that fertility is unrestricted at these levels. A closer look at the data shows that among some of the women the birth intervals are definitively longer than would be expected if natural fertility rates applied. In fact, the fourth and the fifth births appear to constitute some kind of a barrier. At these parities the progression rates hardly exceed 0.8 , but when we go on to higher parities, they are again about 0.9 . Thus the parity distribution of the Laestadian females in Larsmo is clearly bimodal with one peak at 4 children and another at 10 children. Thereby it differs clearly from the parity distribution for the Hutterites, who are considered to represent a population with almost natural fertility (Table 1). 
Table 1. The parity distribution for married Laestadian and non-Laestadian females at age 40 in Larsmo, and Hutterite females at age 50. Percent.

\section{Number of children}

Laest.

Non-laest.

$\begin{array}{llll}0 & 1 & 2 & 3\end{array}$

Hutterites*

$\begin{array}{rrrrr}5 & 3 & 4 & 13 & 14 \\ 6 & 11 & 36 & 29 & 12\end{array}$

$6 \quad 11$

Source: Eaton and Mayer (1954).

A rough estimate is that about one-half of the Laestadians have more or less unrestricted fertility while the other half practice family planning. The proportion that restrict their fertility seems to have increased somewhat during the last decade. In an international or historical perspective the Laestadian fertility is not extreme, but thanks to low mortality, net reproduction is certainly among the highest documented after 1970 . A total fertility rate of 6.0 corresponds to a net reproduction rate of about 2.9 .

One very interesting feature of the fertility development among the Laestadians is that fertility must have increased from the first post-war years until the beginning of the $60 \mathrm{~s}$. According to my calculations, the total fertility rate of the Laestadians must have been clearly below 6.0 in the late 40 s while it was almost 6.5 in the beginning of the $60 \mathrm{~s}$. I believe that the main explanation for this development lies in the development and composition of the Laestadian population.

I have not studied the history and development of the Laestadian movement in Larsmo, but it is likely that during the first decades of the century, the difference between the fertility of Laestadians and non-Laestadians was small. General fertility levels were high, and knowledge about effective contraception limited. There was, therefore, no reason for Laestadians to actively oppose contraception and to advocate unrestricted reproduction. Furthermore, at that time most members of the community had been converted as adults and had not grown up in the movement, nor was it invariably the case that both members of a couple were members of the movement. Therefore, the effect of Laestadianism on fertility was small. During the postwar period the situation changed. Medical conditions and living standards improved, and the proportion of second-generation Laestadians increased. Most new marriages were contracted between members of the congregation, and families were more likely to observe the movement's norms. The dramatic decline of fertility among nonLaestadians drew attention to contraception, and emphasis on children being a gift from God hardened, and resulted in increasing fertility. The development during the 80 s indicates that an increasing proportion of the Laestadians has started to practice family planning, yet with rather big families, i.e. three or four children.

\section{Discussion}

The study of the conditions in Larsmo has convinced me that religion, or the revival movement, is the most decisive factor for the high fertility level in the western part of the province of Oulu. However, I believe that high fertility is restricted to those who actually belong to the revival movement. ${ }^{1}$ Due to this, religion must be included in future fertility studies, because geographical region alone cannot give an appropriate explanation of the variations.

1 A similar result was also reported by Tooney et al. (1985), who showed that the high fertility of Mormons in Utah did not increase the level for the rest of the population. 
Although I conclude that religion evidently is a decisive factor for the high fertility level in several municipalities, it is impossible to make more distinct statements about the behavior or to estimate the fertility of the Laestadians using aggregate data. We must realize that a total fertility rate of $2.5-3.0$ is in fact a very low one from a historical or the Laestadian point of view. As late as in the beginning of the $60 \mathrm{~s}$, fertility rates exceeding 5 were not unusual in the provinces of Lapland and Oulu.

The fertility rate for a municipality as a whole depends on the relative size of the Laestadian subgroup. As an example I can mention Pedersöre, a neighboring municipality of Larsmo, which had a total fertility rate of 2.3 for the period $1980-87$. The same branch of Laestadians as in Larsmo is also present in Pedersöre. I have no real reasons to believe that the reproductive behavior of the Laestadians in Pedersöre is different from that in Larsmo, and the lower fertility rate merely reflects the fact that they constitute a much smaller proportion of the total population in the municipality.

The heterogenity of the population with respect to reproductive behavior is also reflected in the parity distribution. In Larsmo this can be observed in a bi-modal distribution. From the official statistics of families the same seems to be the case in most of the high fertility municipalities. There are a great number of very big families, thus indicating a subpopulation with an extreme fertility level. The parity distributions in these municipalities differ remarkably from those for some of the municipalities in the Turku archipelago, where the fertility rate is also rather high, exceeding 2.1. In the latter case fertility seems to be somewhat higher among all women, since very few of them have more than three children.

The demographic development among Laestadians in Larsmo follows rules of its own, and I believe that if we want to understand the past development or forecast the future in an area with a revival movement like Laestadianism, we cannot restrict ourselves to the traditional variables only. We also have to study the development of the movement as such. In the Larsmo case we can ask whether the more conservative group of the Laestadians will accept that an ever-increasing proportion practice family planning, or whether this will lead to a split of the revival. I believe that it is impossible to make forecasts about fertility development unless we know more about this factor.

\section{References}

Eaton, W. and Mayer, Albert J. (1953). The social biology of very high fertility among Hutterites. The demography of a unique population. Human Biology 25: 206-264.

Finnäs, Fjalar (1989). Fruktsamheten i Larsmo. En studie av laestadianismens demografiska konsekvenser (Fertility in Larsmo. A study on the demographic consequences of the Laestadian movement). Forskningsrapport $\mathrm{nr} 8$. Vasa: Institutet för finlandsvensk samhällsforskning.

Finnăs, Fjalar (1991). Fertility in Larsmo. The effect of Laestadionism. To be published in Population Studies.

Forsberg, Karl-Erik (1977). Befolkningsutvecklingen efter år 1749. (Population development after 1749). Svenska Österbottens historia I., pp. 213-303. Svenska Österbottens landskapsförbund.

Fougstedt, Gunnar (1951). Finlands svenska befolkning áren 1936-45. (The Swedish speaking population of Finland in 1936-45). Bidrag till kännedom av Finlands natur och folk. H. 95, n:o 2. Helsingfors: Finska Vetenskaps-Societeten.

Huotari, Voitto (1981). Kirkkomme herätysliikkeet tänään (The revivalist movements of the church today). Helsinki: Kirjapaja.

Myrskylä, Pekka (1976). Syntyvyys. Syntyvyyden kehitys ja alueelliset erot Suomessa (Fertility. Development and regional differences of fertility in Finland). Studies No. 36. Helsinki: Central Statistical Office of Finland. 
Suolinna, Kirsti (1988). Svenska Tornedalen, en geografiskt avgränsad språklig och religiös minoritet (The Swedish Tornedalen, a geographically bordered linguistic and religios minority). In: Självstyrelseregioner och minoriteter i Europa. Nordens institut pả Ảland.

Tooney, Michael B.; Golesorkhi, Banu and Stinner William F. (1985). Residence exposure and fertility expectations of young Mormon and non-Mormon women in Utah. Journal of Marriage and the Family 47 (2): $459-465$. 